\title{
Financial Technology in Islamic View
}

\author{
Taofik Hidajat* \\ Sekolah Tinggi IImu Ekonomi Bank BPD Jawa Tengah, Semarang, Indonesia
}

The development of financial technology made many changes, including Islamic finance. This paper examines how financial technology changes the world of finance, especially Islamic finance, by using one of the strategies of qualitative research methodology, namely, literature study. This paper is a viewpoint, which covers how fintech is changing the shape of the Islamic finance industry through mobile payments, microfinance, peer-to-peer lending, and crowdfunding. The method used is through literature review in scientific journals and textbooks. The results show that the use of e-wallet does not violate the provisions. Microfinance cannot be separated from Islamic finance if we want to increase social welfare through inclusive growth and encourage the distribution of wealth. Islamic microfinance structure can deal with the problem of poverty. The appropriate and fair crowdfunding model for small businesses is profit sharing or using mudaraba contracts. In Islamic finance, the role of Bitcoin is controversial.

Keywords: Islamic Finance, Fintech, E-wallet, Microfinance, Crowdfunding

OPEN ACCESS

ISSN 2503-3077 (Online) (online) ISSN 2503-3077 (print)

*Correspondence: Taofik Hidajat inidotcom@yahoo.com

Received: 10 August 2020 Accepted: 10 September 2020 Published: 10 October 2020

Citation: Hidajat T (2020) Financial Technology in Islamic View. Perisai : Islamic Banking and Finance Journal. 4:2. doi: 10.21070/perisai.v4i2.465 


\section{INTRODUCTION}

Financial technology (fintech) is the fastest growing technology and financial sector in the financial domain (Alam et al., 2019). Fintech states the financial solution to financial difficulties backed by advanced informational technology.

According to the National Digital Research Center (NDRC), fintech is a term to refer to innovations in financial services. The main objective is to assist the government in encouraging financial inclusion by maximizing the use of technology in various aspects of financial services. Fintech has the opportunity to improve the quality of human life through transparency, cost reduction, eliminating the role of intermediaries, and easier access to financial information (Zavolokina et al., 2016). Fintech exists to bridge the community that is not reached by financial services (Salampasis and Mention, 2018).

It first appeared in the UK; fintech came in the form of a peer-to-peer (P2P) lending named Zopa. At that time, Zopa saw an opportunity to present financial services in the form of easy access, reasonable interest, and promising investments. After that, there was the Funding Circle, which distributed more than 40,000 loans to small businesses. After success in Europe, several countries such as America and China began using Fintech. Today, China even has phenomenal digital financial growth (Zhou et al., 2018) with the most massive P2P lending in the world (Stern et al., 2017). The majority of banks in China focus on digital and fintech services by investing in many fields such as blockchain, big data, and artificial intelligence.

After the high use of digitization, fintech expanded greatly. The digital innovation has extended to incorporate more advancement in the financial area, for example, improvements in budgetary proficiency and its education, banking, and investing. Up to this point, the fintech industry has seen the growth exponentially from 2011. The Pulse of Fintech 2018 (KPMG, 2018) mentions that Southeast Asia is the target of global growth and expansion of fintech. Many companies, especially from China, are investing on a large scale in several countries in Southeast Asia.

According to the Asosiasi Fintech Syariah Indonesia (AFSI), the distribution of sharia fintech loans in Indonesia reached IDR 1 trillion in 2019, a significant increase compared to the previous year of IDR 60 billion. At present, there is 120 sharia fintech registered at AFSI and 12 sharia-based peer to peer lending that have been registered with the Financial Services Authority (OJK). Fintech Syariah has a huge prospect in Indonesia because it has the largest Muslim population in the world.

The growth of fintech will ultimately affect the performance of the financial industry, especially banking. Phan et al. (2019), who studied the growing fintech market in Indonesia, showed that fintech company growth negatively affected bank performance. Therefore, there will be impacts on financial institutions, including Islamic financial institutions. In Indonesia, fintech has embraced the idea of financial inclusion, such as fund- ing less developed sectors and small and micro-enterprises. Fintech also helps to collect and distribute Islamic social funds such as infaq, waqf and sadaqah (Ali, 2020).

Fintech presents the best opportunity for the Islamic banks and the shariah-compliant other financial institutions to increase their scope and scale by using advanced technology and enhance their profits as well as bring convenience and ease to business to their customers and clients. Fintech would help IFIs (Islamic Finance Institutions) to be in the international race of competition, increase their market share significantly. Although some people still prefer to use brick and mortar structure for doing transactions, this segment is negligible. Therefore, Islamic finance needs to take into account all the prospects of doing business on online platforms. According to Hasnan (2019), although Islamic financial countries have high financial inclusion, countries with conventional finance have a higher number of fintech users.

Fintech can be used for the Shariah-compliant solutions that are relevant to generation, accessible, faster, and relatively inexpensive than the other means as they are backed by advanced technology (Todorof, 2018). According to Navaretti, Calzolari, Mansilla-Fernandez, \& Pozzolo (2018), fintech covers four areas namely (i) credit, deposits, and capitalraising services; (ii) payments, clearing and settlement services, including digital currencies; (iii) investment management services including trading; and (iv) insurance.

[Table 1 about here.]

Source: Adapted from BIS (2018) and Navaretti et al. (2018)

The backbone of fintech is blockchain technology (Pilkington, 2016). Through blockchain technology, fintech leaps far ahead and changes the order in the financial sector. Blockchain is a technology that does not require the presence of third parties in a data exchange process. Liu et al. (2020), who analyzed 629 articles in the Web of Science database, concluded that the hottest topics of fintech were mobile payments, microfinance, peer-to-peer lending, and crowdfunding. This paper reviews how fintech changed the shape of the Islamic financial industry through this aspect.

\section{METHODOLOGY}

According to Millan (1993), there are four data collection strategies in qualitative research, namely participatory observation, in-depth interviews, literature and artefact studies, and complementary techniques. This paper uses a qualitative research methodology strategy, namely, a literature study. As a viewpoint of the article, the data sources for this paper come from scientific journals and books on financial technology and Islamic finance. The data was collected through article searches in scientific article publishers. 


\section{DISCUSSION}

There are many fintech instruments of conventional banking that can work as Shariah-compliant products in Islamic finance. This paper discusses the hottest topics of fintech, according to Liu et al. (2020), namely mobile payments, microfinance, peer-to-peer lending, and crowdfunding. In addition to these topics, the role of blockchain in Islamic finance is also discussed. In the future, blockchain will become a research trend and influence the fintech business model.

\section{E-Wallet}

Slowly, cash payments are replaced by cashless via electronic wallet (e-wallet). E-Wallet works just like a wallet but electronically. E-wallet is the advanced form of fintech, which enables its users to pay any bills, fees, or perform microtransactions (Todorof, 2018). It makes the day to day life of a person comfortable and hassle-free. The transaction process begins with the registration of users and business owners on the e-wallet provider's online platform. When a transaction takes place, the buyer pays to use e-wallet on the online e-commerce platform Nashirah et al. (2020).

Unlike e-Money, the use of e-Wallet refers to server-based electronic money, so users must be connected to the publisher's server and the internet. There are two types of e-wallet, ewallet from banks and non-banks. E-wallet from a bank is a virtual wallet service from a bank linked to a customer's account. Non-bank e-wallets, on the other hand, are issued by non-bank providers.

In Indonesia, 38 e-wallets get official licenses. The research collaboration of iPrice Group and App Annie, which was released on August 12, 2019, provides an overview in the second quarter of 2019, the three e-wallets that dominated were Gopay, OVO, and DANA. Seven other e-wallets are LinkAja, Jenius, Go Mobile By CIMB, i.saku, Sakuku, DOKU, and Paytren eMoney iPrice (2019). These results indicate that ewallets belonging to banks become excellent users of e-wallets in Indonesia. It is not surprising because e-wallets are connected to user accounts at the bank. In the second quarter of 2019, four bank e-wallet applications were ranked in the top 10 most active monthly users; namely Jenius, Go Mobile by Cimb, Sakuku, and Mega Mobile.

Since the fourth quarter of 2017, e-wallet applications from non-bank providers Go-Jek, DANA, Paytren, and DOKU have increased by $50 \%$. Low financial inclusion is an opportunity for internet-based fintech companies to expand their reach. The potential for e-wallet development is predicted to be even higher due to Indonesia's demographic bonus in 2030. At that time, the population of productive age is enormous. Jakpat's research, in collaboration with DailySocial, states that $74.6 \%$ of e-wallet application users are of productive age.

In Indonesia, an e-wallet that has sharia features is LinkAja. One thing that most distinguishes from conventional services is the floating fund for top-up balances using the services of an
Islamic bank. LinkAja cooperates with 11 waqf institutions, 23 zakah institutions, 67 donation institutions, and 1000 mosques.

E-wallet contains elements of Wadia (entrusted). When users deposit money to the provider, the money is deposited. Wadia is a deposit that must be maintained and returned every time the owner wants it. Providers may also give bonuses or gifts to the owner on the condition that they are not mentioned in the contract or promised in the contract. If the issuer uses the electronics with the permission of the cardholder, the deposit agreement (wadia) changes to a loan agreement (qardh).

In Majmu'al-Fatwa, muamalah is mubah unless there is an Al Quran or Al-Hadith that forbids (Ibnu, 1995). Therefore, the use of e-wallet is as long as it does not violate the provisions. The problem is that e-wallets are widely used for payments and e-commerce transactions. It is possible that there are transactions that are not Islamic. Thus, there needs to be a mechanism that guarantees that all transactions are free from elements of usury (interest), gharar (uncertainty), and maisir (gambling).

\section{Islamic Microfinance}

The development of the world economy cannot be separated from the role of microfinance or microcredit. Microfinance is financial services for entrepreneurs and small businesses that do not have access to banking and financial services. Microfinance is the main focus to alleviate poverty, reduce unemployment, and empower people through increased economic activity. Microfinance provides a variety of financial services targeting low-income people and small traders who cannot get loans from banks.

Microfinance, spearheaded by Muhammad Yunus, helps those without access to finance by providing capital to start a business and work towards financial independence. Without microfinance, these groups may have to borrow at highinterest rates. Hossain and Wadood (2020), who examined slum dwellers in Dhaka, Bangladesh, stated that microfinance has a positive impact on income or expenditure variables such as savings, education spending, and transportation expenditure.

However, aggressive microfinance growth consistently results in cost inefficiencies (Yimga, 2018). Some research suggests that microfinance fails and loses its mission because many borrowers use loans to pay for needs or fund failed businesses. In South Africa, ninety-four percent of microloans are used for consumption, not for productive activities.

Despite the weaknesses of microfinance, this platform has proven to be useful if done correctly. There is much research that states that microfinance has a positive effect on financial inclusion.

In Indonesia, microfinance institutions are regulated by law. According to the law, microfinance institutions are financial institutions specifically established to provide business development services and community empowerment, either through loans or financing in micro-scale businesses to members and the community, savings management, or providing 
business development consulting services that are not merely looking for profit. It means that microfinance institutions are intermediaries who not only seek profit (profit motive) but also have other goals, namely social objectives (social motive) that are community development.

In addition to carrying out activities conventionally, microfinance can also operate according to sharia principles. There are four models of conventional microfinance institutions, namely (i) grameen bank, (ii) village model, (iii) credit union, and (iv) self-help groups. Even though the four models do not conflict with Islamic principles, there are differences in products and strategies to marginalized segments Shafique (2013).

According to Obaidullah (2008), Islamic microfinance instruments are divided into two, namely charity based and profit-based microfinance instruments. Charity based microfinance instruments are instruments to help and do not have a financial profit orientation. The targets of this category are those who are poor, unproductive, and need funds for basic needs. The instruments in this category are 1) zakah, sadaqa \& waqf, and 2) qard hasan. Profit-based microfinance instruments are business transaction instruments that are oriented towards financial profit. Instruments in this category are 1) Financing (Murabaha, Mudaraba, Musharaka, diminishing Musharaka, Salam and Istishna), 2) Rental (Ijara), 3) Savings (Wadia, Qard, Mudaraba), and 4) Insurance (Takaful).

[Figure 1 about here.]

Source: Obaidullah (2008)

Fan et al. (2019), who compared sharia and conventional microfinance institutions, found that sharia-compliant sharia microfinance institutions had less credit risk. Although it is less profitable, it can reach the poor and less likely to deviate from the mission. It shows that although Islamic microfinance is still a small part of microfinance, Islamic microfinance has excellent potential for growth.

Islamic microfinance is a vehicle for promoting financial inclusion (Rhule, 2016). Microfinance cannot be separated from Islamic finance if we want to increase social welfare through inclusive growth and encourage the distribution of wealth. Islamic microfinance structure can deal with the problem of poverty. However, the reach of Islamic microfinance is still shallow and is concentrated in only a few countries. At present, Islamic microfinance is concentrated in three countries, namely Indonesia, Bangladesh, and Sudan. It is estimated that $72 \%$ of the population in countries where the majority of the population is Muslim does not use financial services because existing financial services are not following Islamic principle (Juliette, 2013).

In Indonesia, before Law No. 1 of 2013 was born, Islamic microfinance institutions are Baitul Mal wa Tamwil (BMT) or Koperasi Simpan Pinjam dan Pembiayaan Syariah (KSPPS). BMT or KSPPS is a microfinance institution in the form of a cooperative that operates based on sharia principles to provide capital to the micro and the small business community.

\section{Peer-to-peer Lending and Crowdfunding}

Crowdfunding is a digital economy where a large number of individuals collect and distribute funds through online platforms to people and institutions (Langley, 2016). It is also defined as the debt financing instrument where a borrower can lend money from any creditor without involving any financial intermediaries. Financial intermediaries increase the cost for the borrower, thus discoursing cost-conscious borrowers (Todorof, 2018). All the definitions of the crowdfunding entail three significant points: advanced technology, the strength of the mass, and the "capital funding." These aspects of the crowdfunding enabled the small portions to accumulate and became a vital finance source (Beaulieu et al., 2015).

This platform emerged as one of the solutions to overcome the problem of funding sources, especially for new projects (Juliette, 2013). Since finance resource is limited, crowdfunding or crowdlending is the best instrument. It refers to the activity done through the internet in which a person, business association, non-profit concerns, or companies offers to different kinds of people a deliberate responsibility of duty, which may include sharing money, sharing knowledge, or past experiences (Estellés-Arolas and de Guevara, 2012). Although it is a relatively new thing, this platform provides a significant contribution to the business and is a threat to venture capital and angel investors (Vulkan et al., 2016).

According to Harrison (2013), there are several crowdfunding models, namely peer-to-peer lending, reward, equity, donation, and pre-purchase. The crowdfunding category from Massolution (2012) is loaning-based, rewardbased, equity-based, and donation-based. In the loan-bases crowdlending, the lenders require the fixed monthly cash inflows and the repayment of the original loan amount. In reward-based crowdlending, the lenders invest and expect a non-monetary reward on investment. On the other hand, in equity-based crowdlending, the creditors get the output based on the borrower's profit-sharing or equity sharing. In the last donation-based crowdlending, the investor donates without expecting anything from the other party.

This instrument can be used for shariah-compliant equity financing on the bases of mudaraba, musharakah, diminishing musharakah, or murabaha. In mudaraba, one person provides the money, and others use his/ her skills to earn profit from that money. In musharakah, two investors invest and earn or divide profits among them. In diminishing musharakah, one person share in investment keeps decreasing as other pay the amount (Hidayat, 2011). According to shariah context, risk sharing is compulsive for the profit to be titled as halal, as crowdlending is risky; crowdlending is halal and shariah-compliant. In contrast to conventional loans, the lending model in sharia is based on a profit-loss partnership (Pişkin and Kuş, 2019). Shariah-compliant is used for which investment is mentioned in Table 2.

[Table 2 about here.] 
Source: Marzban et al. (2014)

The appropriate and fair crowdfunding model for small businesses is profit sharing or using mudaraba contracts (Hidajat et al., 2016). Mudaraba is a contract of pilgrimage, which is a contract for profit but while maintaining sharia principles. It is a fair contract compared to conventional contracts where investors get profits even if the borrower loses money. In mudaraba, if there is a profit, investors (sahib al-mal) and entrepreneurs (mudarib) will share according to the agreement. However, if losers, investors bear these losses.

\section{Cryptocurrency}

With the emergence of cryptocurrency, financial technology has been revolutionized. Bitcoin is the most critical component of cryptocurrency. Cryptocurrency is a decentralized digital coin that works as a medium of exchange, and the transactions are done without the involvement of any bank or a middleman.

The deals are done with the help of a system named the blockchain. All the balances are recorded on that digital public ledger. The transactions are recorded in a public ledger, which gives the surety to verify the payment method. There is no role of the central government in these entire scenarios Bakar et al. (2018). It is controlled electronically by users, and the coins are digitally sent to the other person.

Cryptocurrency wallets are used to do the transaction among people. These wallets are backed with a password. Transactions are processed with the help of miners. Miners are the persons who are handling public ledgers. They solve different puzzles with the help of software, and then the transactions are added to the ledger. These are the people who confirm the transactions by breaking different codes.

As a consequence, they are given some coins for their services, known as cryptocurrency mining. When the cryptocurrency transaction is made, the digital wallets use an electronic signature, which indicates that it has come from the wallet's holder. The deal is matched with the name. Cryptographic is a system that is used to regulate the creation and verification of transactions. There is just a need to have an account or password. Once the blockchain records are added, it is not erasable, until the majority of the participants of the system.

According to the USA Congressional Research Service Report, bitcoins can be used as a medium of exchange; if someone wants to sell his product or service, then he can exchange it with the bitcoin. Initially created in 2009 by Satoshi Nakamoto, bitcoin is an 'alternative' payment instrument that is conducted on a peer-to-peer basis.

However, bitcoin is not just a means of payment because it is a commodity that is traded. Bitcoin even has a speculative bubble with the original price of zero (Cheah and Fry, 2015). Many bitcoin traders do not know how blockchain technology works. Their involvement in cryptocurrencies is due to psychological factors (Hidajat, 2019).

In Islamic terms or Islamic finance, as per Shariah, the role of bitcoin is controversial. Some are of the view that it is Islam- ically covered, and some have a look that it cannot be accepted as a medium of exchange as it does not come under the definition of "money." According to Yussof and Harthy (2018), they have included the description of money in which Danish central bank states that Bitcoins cannot be considered as proper money because no issuer backs it, they do not have any physical form. Bitcoin is not backed up by the government or central bank. Therefore it cannot be used as a medium of exchange.

Yussof and Harthy (2018), in their study, have quoted that Imran Hosein, who is a very famous Islamic finance Scholar, according to him, In Islam, the money has six characteristics, i.e., money is in excess form, and it is not easy to get perished. Money has some fundamental value, and above all, money can be exchanged with other things. According to Imran Hosein, Bitcoins do not come under these dimensions of Islam; that is the reason it is cannot be aligned with Shariah. They can be made compatible with Shariah if they fall in the definition of money or backed by the government.

On the other side of the picture, the blockchain technology of bitcoin can be made Shariah compliant if it is done under the rules and regulations of musharakah (Evans, 2015). According to Evans (2015), it has been seen that the blockchain system, which is known as virtual currency, does not incorporate riba, and it works in the mutual risk-sharing principle. Miners can operate as partners in the case of musharakah. Hence, one should make the use of such things that are Shariah compliant and if there is no doubt about using such a thing.

\section{CONCLUSION}

Islamic finance and banking are increasing day by day. It is appealing to billions of Muslims present around the world. The world has seen the popularity of Islamic banking and finance among the non-Muslims due to its design as real assets back it. Compared to that, Islamic financing is still raw needs vast improvements.

Technology can provide the opportunity to Islamic banks to increase their scope in comparison to the conventional bank and even adopt the products of the conventional banks that are shariah-compliant and or also convert some aspect of nonshariah compliant products to make it according to shariah. These suggestions or steps are in the best interest of the Islamic finance intuitions to beat their global competitors in the long run.

Further, the added benefit of advanced technology is that it gives all the financial transactions transparency. Islamic banks, customers, and the state can track all the transactions whenever they need them. While talking about the instruments of FinTech, crowdfunding would fill the gap present today in Islamic banking for equity and debt investment that is present for individual investors as well as for small and medium enterprises. Fintech does not include crowdlending, mobile wallets, or bitcoins; its scope is more extensive and broader than this. Fintech includes already established contracts that can reduce the risk 
attached to a product (hedging). Blockchain is a vast concept that can be used to reduce the complexity of a transaction over some time.

Fintech is currently in use by many countries. However, all these technologies are in their early stages and need improve-

\section{REFERENCES}

Alam, N., Gupta, L., and Zameni, A. (2019). Fintech and Islamic Finance.

Ali, H. F. (2020). How does Islamic fintech promote the SDGs? Qualitative evidence from Indonesia. Qualitative Research in Financial Markets.

Bakar, N., Abu, and Rosbi, S. (2018). Robust framework diagnostics of Blockchain for bitcoin transaction system: A technical analysis from Islamic Financial Technology (i-FinTech) perspective. International Journal of Business and Management 2, 22-29.

Beaulieu, T., Sarker, S., and Sarker, S. (2015). A Conceptual Framework for Understanding Crowdfunding. Communications of the Association for Information Systems 37. doi: 10.17705/1 cais.03701.

BIS (2018). Sound Practices: Implications of fintech developments for banks and bank supervisors. Bank for International Settlements.

Cheah, E.-T. and Fry, J. (2015). Speculative bubbles in Bitcoin markets? An empirical investigation into the fundamental value of Bitcoin. Economics Letters 130, 32-36. doi: 10.1016/j.econlet.2015.02.029.

Estellés-Arolas, E. and de Guevara, F. G.-L. (2012). Towards an integrated crowdsourcing definition. Journal of Information Science 38, 189-200. doi: 10.1177/ 0165551512437638.

Evans, C. (2015). Bitcoin in Islamic banking and finance. Journal of Islamic Banking and Finance 3, 1-11.

Fan, Y., John, K., Liu, F. H., and Tamanni, L. (2019). Security design, incentives, and Islamic microfinance: Cross country evidence. Journal of International Financial Markets, Institutions and Money 62, 264-280. doi: 10.1016/j.intfin.2019.08.002.

Harrison, R. (2013). Crowdfunding and the revitalisation of the early stage risk capital market: catalyst or chimera?

Hasnan, B. (2019). Financial inclusion and FinTech: A comparative study of countries following Islamic finance and conventional finance. Qualitative Research in Financial Markets 12, 24-42.

Hidajat, T. (2019). BEHAVIOURAL BIASES IN BITCOIN TRADING. doi: 10.34152/fe.14.2.337-354. https://dx.doi.org/10.34152/fe.14.2.337-354.

Hidajat, T., Primiana, I., Nidar, S., and Febrian, E. (2016). Crowd funding: financial service for unserved crowds in Indonesia. In International Conference, Integrated Microfinance Management for Sustainable Community Development(IMM 2016) (Atlantis Press).

Hidayat, T. (2011). Buku Pintar Investasi Syariah (Mediakita).

Hossain, B. and Wadood, S. N. (2020). Impact of urban microfinance on the livelihood strategies of borrower slum dwellers in the Dhaka city, Bangladesh. Journal of Urban Management 9, 151-167. doi: 10.1016/j.jum.2019.12.003.

Ibnu, T. (1995). Mujamma Al Malik Fahd Lithiba’atil Mushaf. (Madinah: Majmu'Al fatawa).

iPrice (2019). Siapa Aplikasi E-wallet dengan Pengguna Terbanyak di Indonesia?

Juliette (2013). What is islamic Microfinance ? https://www.microworld.org/en/ news-from-the-field/article/what-islamic-microfinance.

KPMG (2018). The Pulse of Fintech.

Langley, P. (2016). Crowdfunding in the United Kingdom: A Cultural Economy. Economic Geography 92, 301-321. doi: 10.1080/00130095.2015.1133233.

Liu, J., Li, X., and Wang, S. (2020). What have we learnt from 10 years of fintech research? a scientometric analysis. Technological Forecasting and Social Change $155,120022-120022$.

Marzban, S., Asutay, M., and Boseli, A. (2014). Shariah-compliant crowd funding: An efficient framework for entrepreneurship development in Islamic countries. Eleventh Harvard International Islamic Finance Form. ments and clarification for the customer that how these technologies are shariah compliant. In a nutshell, Islamic banks other IFIs have multiple options to which instrument to select in their working and increase their compatibility with today's world and, at the same time, remain shariah compliant.
Massolution, C. L. L. C. (2012). Crowdfunding industry report: market trends, composition and crowdfunding platforms.

Millan, M. (1993). Jamesh dan Sally Schumacer. tt. In Research in Education.

Nashirah, A. B., Rosbi, S., and Uzaki, K. (2020). E-Wallet Transactional Framework for Digital Economy: A Perspective from Islamic Financial Engineering. INTERNATIONAL JOURNAL OF MANAGEMENT SCIENCE AND BUSINESS ADMINISTRATION 6, 50-57. doi: 10.18775/ijmsba.1849-5664-5419.2014.63. 1005.

Navaretti, G. B., Calzolari, G., Mansilla-Fernandez, J. M., and Pozzolo, A. F. (2018). Fintech and Banking. Friends or Foes? Friends or Foes.

Obaidullah, M. (2008). Introduction to Islamic microfinance. IBF Net Limited.

Phan, D. H. B., Narayan, P. K., Rahman, R. E., and Hutabarat, A. R. (2019). Do financial technology firms influence bank performance? Pacific-Basin Finance Journal.

Pilkington, M. (2016). Blockchain technology: principles and applications. Research handbook on digital transformations.

Pişkin, M. and Kuş, M. C. (2019). Islamic Online P2P Lending Platform. Procedia Computer Science 158, 415-419. doi: 10.1016/j.procs.2019.09.070.

Rhule, K. (2016). Islamic Microfinance: a Vehicle for Promoting Financial Inclusion.

Salampasis, D. and Mention, A. L. (2018). Chapter 18 - FinTech: Harnessing Innovation for Financial Inclusion. of B. Deng Digital Finance, and Inclusion 2, 451-461.

Shafique, B. (2013). Models of Islamic Microfinance.

Stern, C., Makinen, M., and Qian, Z. (2017). FinTechs in China - with a special focus on peer to peer lending. Journal of Chinese Economic and Foreign Trade Studies 10, 215-228. doi: 10.1108/jcefts-06-2017-0015.

Todorof, M. (2018). Shariah-compliant FinTech in the banking industry. ERA Forum 19, 1-17. doi: 10.1007/s12027-018-0505-8.

Vulkan, N., Åstebro, T., and Sierra, M. F. (2016). Equity crowdfunding: A new phenomena. Journal of Business Venturing Insights 5, 37-49. doi: 10.1016/j.jbvi.2016. 02.001 .

Yimga, J. (2018). Microfinance expansion and its effects on cost efficiency. The Quarterly Review of Economics and Finance 69, 205-216. doi: 10.1016/j.qref.2018.03. 006.

Yussof, S. A. and Harthy, A. (2018). Cryptocurrency as an Alternative Currency in Malaysia: Issues and Challenges. Islam and Civilisational Renewal.

Zavolokina, L., Dolata, M., and Schwabe, G. (2016). FinTech-What's in a Name?

Zhou, W., Arner, D. W., and Buckley, R. P. (2018). Chapter 3 - Regulating FinTech in China: From Permissive to Balanced. of B. Deng Digital Finance, and Inclusion $2,45-64$

Conflict of Interest Statement: The author declare that the research was conducted in the absence of any commercial or financial relationships that could be construed as a potential conflict of interest.

Copyright (C) 2020 Hidajat. This is an open-access article distributed under the terms of the Creative Commons Attribution License (CC BY). The use, distribution or reproduction in other forums is permitted, provided the original author(s) and the copyright owner(s) are credited and that the original publication in this journal is cited, in accordance with accepted academic practice. No use, distribution or reproduction is permitted which does not comply with these terms. 


\section{LIST OF TABLES}

1 Fintech Services by Sector . . . . . . . . . . . . . . . . . . . . . . . . . 109

2 Crowdlending model and Shariah compliant instrument

110 
TABLE 1 | Fintech Services by Sector

\section{Sectoral Innovations}

Credit, deposit and capital-raising

services

Crowdfunding

Lending marketplaces

Mobile banks

Credit scoring
Payments, clearing and settlement services

Wholesale

Retail

Mobile wallets

Peer-to-peer

transfer

Digital currencies
Investment management

services

High-frequency trading

Copy trading

E-trading

Robo-advice
Insurance

Link to mobile

devices

Big data

Improved risk pricing

New contracts 
TABLE 2 | Crowdlending model and Shariah compliant instrument

\begin{tabular}{lll}
\hline Investment required for & Crowdlending model & Shariah compliant instrument \\
Charity & Donation & Qard-e-hasna Hiba \\
Product & Reward & Sale \\
Investment & Debt & Murabaha ljara \\
& Investment & Musharakah Mudaraba Dimishing Musharakah \\
\hline
\end{tabular}




\section{LIST OF FIGURES}

1 Islamic Microfinance Instruments 


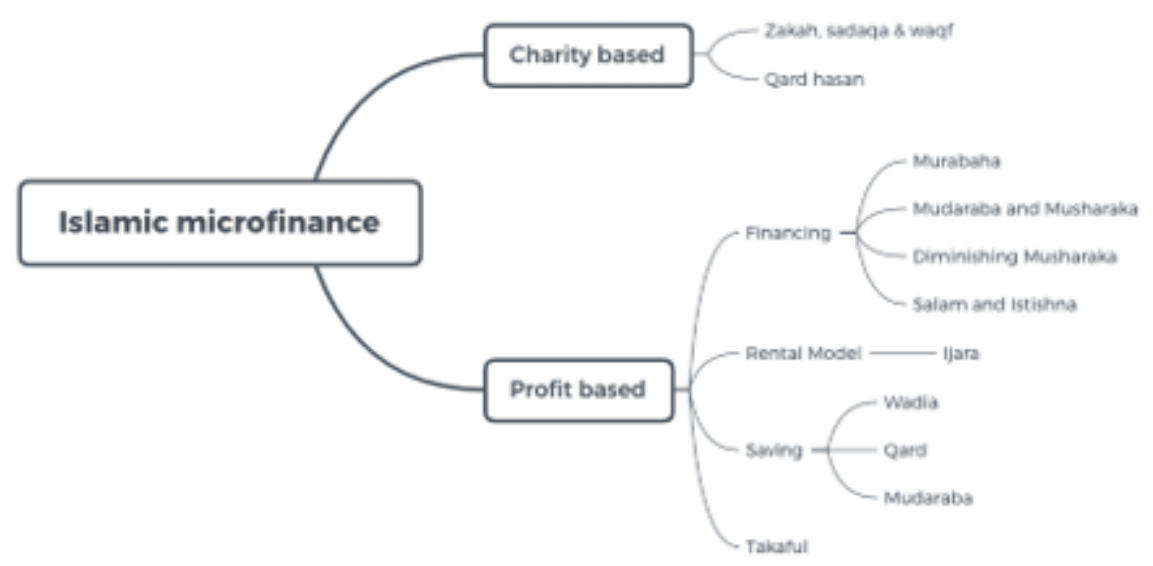

FIGURE 1 | Islamic Microfinance Instruments 